\title{
Lymphocyte surface marker expression in rheumatic diseases: evidence for prior activation of lymphocytes in vivo
}

\author{
Malcolm D Smith, Peter J Roberts-Thomson
}

\begin{abstract}
Expression of major histocompatibility complex (MHC) class II and other lymphocyte activation markers on peripheral blood and synovial fluid $T$ lymphocytes from patients with rheumatoid arthritis (RA), psoriatic arthritis, and Reiter's syndrome were measured and the mean fluorescence intensities of these antigens were assessed. Increased expression of MHC class II antigens of synovial fluid T lymphocytes is not unique to RA, though it is quantitatively greater on RA synovial fluid $T$ cells. There was less expression of other lymphocyte activation markers (4F 2 , transferrin receptor) and a marked discordance between the expression of these markers and the interleukin 2 receptor (IL2r). Synovial fluid $T$ lymphocytes contain a subpopulation of larger cells expressing MHC class II and other lymphocyte activation antigens with the exception of the IL2r. Mean fluorescence intensity of CD3 and CD4 antigens on synovial fluid $\mathbf{T}$ lymphocytes was decreased in all three patient groups, suggesting prior in vivo exposure of synovial fluid $\mathbf{T}$ lymphocytes to an unknown antigen.
\end{abstract}

Rheumatoid arthritis (RA) is a chronic inflammatory condition characterised by a marked mononuclear cell infiltrate in synovial tissue and synovial fluid, with $\mathrm{T}$ lymphocytes being prominent. Persistent immunological activity of these $\mathrm{T}$ lymphocytes in response to an unknown antigen is thought to be a major reason for the immunohistological changes seen in RA synovial tissue. Despite this attractive hypothesis there has been controversy about the phenotypic and functional characteristics of $T$ lymphocytes in RA peripheral blood and, particularly, synovial fluid. Although most studies agree about the predominance of CD4 positive $\mathrm{T}$ cells in peripheral blood and CD8 positive $T$ cells in synovial fluid of patients with $\mathrm{RA},{ }^{1-11}$ there is disagreement about the predominant $T$ cell subset in RA synovial tissue..$^{11-15}$ Greater differences can be found in published studies reporting on lymphocyte activation markers (including major histocompatibility complex (MHC) class II antigens, interleukin 2 receptor (IL2r), transferrin receptor) expressed on RA peripheral blood and synovial fluid lymphocytes. Some studies have reported increased expression of IL2r and transferrin receptor on RA peripheral blood ${ }^{1516}$ and synovial fluid ${ }^{15} 1718$ $\mathrm{T}$ lymphocytes, whereas other studies have found little or no increased expression of these markers on peripheral blood ${ }^{311} 17$ or synovial fluid T lymphocytes. ${ }^{3}{ }^{11}$ Most studies agree that there is a considerable discordance between the markedly increased MHC class II expression and the marginal increase in IL2r expression on RA synovial fluid T cells, ${ }^{3} 11151718$ in contrast with the coexpression of these antigens on $T$ lymphocytes stimulated in vitro. ${ }^{17-19}$

Similar controversy exists about the functional state of these $T$ cells, particularly relating to the presence of IL2 in RA synovial fluid and the ability of RA peripheral blood and synovial fluid $\mathrm{T}$ lymphocytes to produce IL2, express IL2r, and respond to exogenous IL2. ${ }^{20-25}$

Increased size of $T$ lymphocytes in $R A$ synovial fluid has been reported, similar to that of in vitro stimulated peripheral blood lymphocytes from normal subjects, suggesting that the $T$ lymphocytes are 'activated' 61518 Recent studies on RA synovial fluid $^{23}$ and synovial tissue $^{26} \mathrm{~T}$ lymphocytes have shown downregulation of the CD3 antigen and expression of late 'activation' markers ${ }^{26} 27$ on these cells, suggesting prior activation of intraarticular $T$ cells in vivo.

There have been few publications examining the phenotypic or functional characteristics of $T$ lymphocytes in other inflammatory arthritides. ${ }^{11} 2829$ Patients with inflammatory arthritides have sometimes been included in a control group for comparison with the findings in patients with RA. Therefore the specificity of the $\mathrm{T}$ lymphocyte phenotypic and functional characteristics for RA is unknown. We report our findings on the phenotypic characteristics of peripheral blood and synovial fluid $T$ lymphocytes in a large group of patients with $\mathrm{RA}$ as well as a group of patients with psoriatic arthritis and Reiter's syndrome. The functional characteristics of the $T$ cells in these patient groups are reported elsewhere. ${ }^{30}$

Patients and methods

PATIENTS AND CONTROLS

Table 1 presents details of the patients studied. All patients with RA had classical or definite $\mathrm{RA}^{31}$ and all patients with psoriatic arthritis had an asymmetrical polyarthritis with a persistently negative rheumatoid factor and a personal or family history of psoriasis. All patients with Reiter's syndrome conformed to the American Rheumatism Association criteria for definite Reiter's syndrome ${ }^{32}$ and had persistently negative rheumatoid factor tests. All patients with crystal arthritis had a history of acute monoarthritis with a synovial fluid cell content consisting mainly of neutrophils containing intracellular monosodium urate or calcium 
Table 1: Clinical and laboratory indices for the patient groups studied

\begin{tabular}{|c|c|c|c|c|c|c|}
\hline & $R A^{*}$ blood & $R A S F^{*}$ & $P A S F^{*}$ & $R S S F^{*}$ & $C A S F^{*}$ & Control blood \\
\hline $\begin{array}{l}\text { Number } \\
\text { Mean age (years) } \\
\text { Sex (M:F) } \\
\text { Disease duration (years) } \\
\text { NSAIDs** } \\
\text { SAARDs* }\end{array}$ & $\begin{array}{l}55 \\
65 \cdot 8 \\
23: 32 \\
6 \cdot 6 \\
54\end{array}$ & $\begin{array}{l}44 \\
64 \cdot 06 \\
18: 26 \\
6 \cdot 94 \\
38\end{array}$ & $\begin{array}{c}10 \\
43 \\
7: 3 \\
4: 6 \\
6\end{array}$ & $\begin{array}{l}15 \\
30 \\
13: 2 \\
2 \cdot 2 \\
5\end{array}$ & $\begin{array}{c}6 \\
66 \\
5: 1 \\
3 \cdot 8 \\
6\end{array}$ & $\begin{array}{l}55 \\
60 \cdot 4 \\
23: 32 \\
- \\
20+\end{array}$ \\
\hline Gold & 8 & 5 & 1 & 0 & 0 & - \\
\hline D-Penicillamine & 5 & 5 & 0 & 0 & 0 & - \\
\hline Sulphasalazine & 3 & 0 & 0 & 0 & 0 & - \\
\hline Methotrexate & 2 & 2 & 1 & 0 & 0 & - \\
\hline None & 37 & 32 & 8 & 15 & 6 & 55 \\
\hline Steroids & 3 & 3 & 0 & 0 & 0 & 0 \\
\hline $\mathrm{CRP}^{*}(\mathrm{mg} / \mathrm{l})$ & $51 \cdot 7$ & $34 \cdot 6$ & 20 & $33 \cdot 8$ & 35 & $<6 \ddagger$ \\
\hline $\mathrm{RF}^{*}(\mathrm{IU} / \mathrm{ml})$ & 1608 & 1158 & $<60$ & $<60$ & $<60$ & $<60 \ddagger$ \\
\hline IgG (g/l) & 13.08 & 9.54 & 5.55 & $6 \cdot 68$ & 8.53 & $7-19 \ddagger$ \\
\hline $\operatorname{IgM}(g / \mathbf{l})$ & 1.99 & 0.99 & 0.83 & 0.57 & $1 \cdot 16$ & $0.55-2.20 \ddagger$ \\
\hline $\operatorname{IgA}(\mathbf{g} / \mathbf{l})$ & $3 \cdot 38$ & $2 \cdot 64$ & 0.83 & $1 \cdot 35$ & $3 \cdot 27$ & $0.50-4.00 \ddagger$ \\
\hline
\end{tabular}

${ }^{*} \mathrm{RA}=$ rheumatoid arthritis; $\mathrm{SF}=$ synovial fluid; $\mathrm{PA}=$ psoriatic arthritis; $\mathrm{RS}=$ Reiter's syndrome; $\mathrm{CA}=\mathrm{crystal}$ arthritis, NSAIDs=nonsteroidal anti-inflammatory drugs; $S A A R D s=$ slow acting antirheumatic drugs; $C R P=C$ reactive protein; $R F=$ rheumatoid factor steroidal anti-inflammatory drugs; SAARDs=slow acting antirheumatic drugs; $\mathrm{CRF}$

†These control sub

pyrophosphate crystals on polarised microscopic examination.

Activity of articular disease was defined by a combination of duration of morning stiffness ( $>30$ minutes), articular index, and laboratory parameters (C reactive protein, erythrocyte sedimentation rate, and synovial fluid white cell count).

Details of age, sex, disease duration, and drugs taken were recorded for all patients studied. Serum and synovial fluid from all patients were analysed for $C$ reactive protein, rheumatoid factor, and immunoglobulin concentrations by rate nephelometry (Beckman Instruments, Brea, $\mathrm{Ca}$ ). The control group were healthy subjects without any known inflammatory condition at the time of study matched for age and sex with the group with RA.

\section{PREPARATION OF MONONUCLEAR CELI} SUSPENSIONS

Most synovial effusions had been present for less than three months and were obtained by percutaneous arthrocentesis of inflamed knee joints. Synovial fluid was processed immediately as previously described. ${ }^{73}$ Mononuclear suspensions from peripheral blood were prepared by Ficoll-Hypaque (Nyegaard) gradient centrifugation. ${ }^{7}$

\section{MONOCLONAL LABELLING TECHNIQUE}

Standard indirect immunofluorescence was used with successive 30 minute incubations at $4^{\circ} \mathrm{C}$ of 10 million mononuclear cells (in $100 \mu \mathrm{l}$ phosphate buffered saline containing $0.02 \%$ azide) with a monoclonal antibody followed by pooled human serum and fluorescein conjugated goat antimouse antibody. ${ }^{7}$ Cells were fixed in phosphate buffered saline containing $1 \%$ paraformaldehyde and stored in the dark at $4^{\circ} \mathrm{C}$ until analysed. Positive (FMC16), negative (X63), and monocyte (FMC33) controls were included in each analysis. Table 2 lists the monoclonal antibodies used.

For dual immunofluorescence studies, directly conjugated antibodies (HLA-DR-fluorescein isothiocyanate (FITC), IL2r-phycoerythrin, IL2r-FITC, Leu2a-phycoerythrin, Leu3aphycoerythrin; Becton Dickinson) were used if available and both direct labelled antibodies were incubated simultaneously. ${ }^{33}$ When direct labelled antibodies were unavailable $(4 \mathrm{~F} 2$, transferrin receptor, FMC56) an indirect immunofluorescent step was followed by incubation with a phycoerythrin labelled monoclonal antibody. Previous studies have shown no cross reaction between the two fluorochromes, ${ }^{33}$ and cells were also single labelled with each antibody (FITC and phycoerythrin labelled) to exclude any cross reaction.

Table 2: Monoclonal antibodies used in indirect immunofluorescence

\begin{tabular}{|c|c|c|}
\hline Monoclonal antibody & Immunoglobulin class & Description \\
\hline $\begin{array}{l}\text { FMC16 } \\
\text { X63 } \\
\text { FMC33(CD14) } \\
\text { OKT4(CD4)** } \\
\text { OKT8(CD8)* } \\
\text { OKT3(CD3)* } \\
\text { Leul(CD5)† } \\
\text { B7/21 } \\
\text { Leul0† } \\
\text { HLA-DR† } \\
\text { FMC14 } \\
\text { FMC56 (CD9) } \\
\text { 4F2 } \\
\text { OKT9* } \\
\text { IL2r£(CD25)† } \\
\text { SMIG } \ddagger \\
\text { Leu7† } \\
\text { Leulib }\end{array}$ & $\begin{array}{l}\text { IgG2a/K } \\
\text { IgGl/K } \\
\text { IgG1/K } \\
\text { IgG2b } \\
\text { IgG2 } \\
\text { IgG2a } \\
\text { IgG2a/K } \\
\text { IgG1/K } \\
\text { IgG2/K } \\
\text { IgG2a/K } \\
\text { IgGl/K } \\
\text { IgG1/K } \\
\text { IgG2a/K } \\
\text { IgGI } \\
\text { IgGl/K } \\
\mathrm{F}(\mathbf{a b})_{2} \\
\text { IgM/K } \\
\text { IgM/K }\end{array}$ & $\begin{array}{l}\text { B2 Microglobulin (positive control) } \\
\text { Mouse myeloma antibody (negative control) } \\
\text { Monocyte/macrophage cells } \text { s. }^{4} \text { ) } \\
\text { Helper/inducer cell } \\
\text { Suppressor/cytotoxic cell } \\
\text { Pan T cell } \\
\text { Pan T cell, subset of B cells } \\
\text { MHCS class II antigen (DP) } \\
\text { MHC class II antigen (DQ) } \\
\text { MHC class II antigen (DR) } \\
\text { MHC class II (DP, DQ, DR) } \\
\text { Mid/late activation marker }{ }^{37} \\
\text { Early activation marker } \\
\text { Transferrin receptor, mid activation marker } \\
\text { Early activation marker } \\
\text { B cell } \\
\text { CD8 and NK cells } \\
\text { CD8 and NK cells }\end{array}$ \\
\hline
\end{tabular}

*Orthodiagnostics Laboratories.

†Becton-Dickinson Laboratories.

Silenus Laboratories.

SIL2 $r=$ interleukin 2 receptor; $M H C=$ major histocompatibility complex; $N K=$ natural killer. 
Fluorescence was analysed on a Becton Dickinson FACS IV analyser using a mercury arc lamp for excitation of both fluorescein and phycoerythrin at a wavelength of $484 \mathrm{~nm}$. Fluorescence emission was detected by selective collecting through photomultipliers at 530 (fluorescein) and 595 (phycoerythrin) $\mathrm{nm}$. Analysis of 10 thousand cells was performed with a Becton Dickinson Consort 30 computer system. Fluorescence analysis was carried out by gating the lymphocytes and delineating positive and negative markers using the positive and negative controls included in each experiment. Monocyte contamination of the gated population was less than $3 \%$ as determined by FMC33 fluorescence. Antigen density was indirectly assessed by measuring the mean fluorescence intensity of the analysed cells for each monoclonal antibody. ${ }^{23}$ Volume analysis was performed by gating for strongly positive cell populations on fluorescence histograms and analysing the volume distribution of this population. ${ }^{18}$

PERIPHERAL BLOOD LYMPHOCYTE STIMULATION Peripheral blood mononuclear cells from control subjects were prepared as above and resuspended in RPMI containing $10 \%$ heat inactivated fetal calf serum (Gibco) at 1 million viable cells (trypan blue exclusion) per $\mathrm{ml}$. Cells were cultured in tissue culture flasks in a $37^{\circ} \mathrm{C}, 5 \%$ $\mathrm{CO}_{2}$ incubator for three to seven days in the presence of OKT3 (Orthodiagnostics) antibody at a final concentration of $2 \cdot 5 \mathrm{ng} / \mathrm{ml}$. At the time of harvesting cells were washed extensively in phosphate buffered saline with azide, adjusted to a concentration of 10 million viable cells (trypan blue exclusion)/ml and labelled as above. Tritiated thymidine (Amersham) uptake was assessed on each day of harvesting to ensure that mitogenic stimulation was adequate.

\section{STATISTICAL ANALYSIS}

An SPSSX computer package was used for statistical analysis. A $t$ test, one way, and multiple analysis of variance and Pearson correlations (corrected for number of comparisons) were performed. Statistical significance was accepted at the $5 \%$ level.

\section{Results}

IMMUNOFLUORESCENCE STUDIES

Single and dual fluorescence studies on CD3 monoclonal antibody stimulated lymphocytes confirmed the early expression of IL2r and 4F2 antigens, which persisted for the seven days of culture. Transferrin receptor was expressed after these two antigens and declined to low levels by the seventh day of culture. MHC class II expression appeared later and did not peak until the seventh day of culture (results not shown). Both CD4 (58\% positive) and CD8 (65\% positive) $\mathrm{T}$ lymphocytes expressed HLADR antigens after mitogenic stimulation and there was concordance between expression of MHC class II, 4F2, IL2 $r$, and transferrin receptor on these lymphoblasts (results not shown).

There were more $\mathrm{CD} 3$ positive cells in synovial fluid samples than in peripheral blood, irrespective of diagnosis. An increase in CD4 positive cells and a decrease in $\mathrm{CD} 8$ positive cells was seen in RA peripheral blood and in synovial fluid from patients with psoriatic arthritis, Reiter's syndrome, and crystal arthritis, while the opposite was seen in RA synovial fluid (table 3). A small but significant increase in MHC class II expression was seen on RA peripheral blood lymphocytes $(p<0.005)$ and a much greater increase on RA synovial fluid lymphocytes $(p<0.005)$ than on control peripheral blood lymphocytes. While most of the RA peripheral blood CD4 lymphocytes were MHC class II negative ( $p<0.005$ compared with CD4+DR+ cells), almost half the CD8 peripheral blood lymphocytes expressed the HLA-DR antigen (table 4). In contrast, there were more CD4+DR+ and CD8+DR+ in RA synovial fluid than in RA peripheral blood $(p<0.005)$, with the predominant lymphocyte subset expressing MHC class II antigen being the CD8 positive cell. There was little coexpression of IL2r with any of the other antigens on the RA peripheral blood or synovial fluid cells (table 4) and there was no increased expression of IL2r, transferrin receptor, or FMC56 on RA peripheral blood or synovial fluid lymphocytes (table 3).

A statistically significant increase in MHC class II expression on synovial fluid lymphocytes from patients with psoriatic arthritis, Reiter's

Table 3: Lymphocyte surface markers on peripheral blood lymphocytes from patients with rheumatoid arthritis and control subjects, and on synovial fluid lymphocytes from patients with rheumatoid arthritis, psoriatic arthritis, Reiter's syndrome, and crystal arthritis. Results are expressed as mean percentage positive cells (SEM)

\begin{tabular}{|c|c|c|c|c|c|c|}
\hline Monoclonal antibody & Control blood & $R A \ddagger$ blood & $R A S F \ddagger$ & $P A \ddagger S F$ & $R S \ddagger S F$ & $C A \mp S F$ \\
\hline $\begin{array}{l}\text { CD3 } \\
\text { CD4 } \\
\text { CD8 } \\
\text { MHC class II } \\
\text { FMC56 } \\
\text { 4F2 } \\
\text { Transferrin receptor } \\
\text { IL2r } \\
\text { SMIG } \\
\text { Leu7 } \\
\text { Leullb }\end{array}$ & 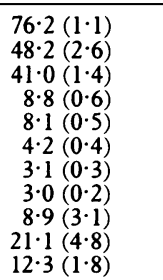 & $\begin{array}{c}73.0(4.4) \\
58.4(3 \cdot 1) \\
29.3(1 \cdot 1) \\
14.8(0.8)^{* *} \\
14.6(0.8)^{* *} \\
7.6(0.7)^{*} \\
4.8(0.5) \\
4.8(0.6) \\
14.4(1.4)^{*} \\
29.4(3.6) \\
17.6(2.4)\end{array}$ & $\begin{array}{l}82.0(1 \cdot 4)^{* *}+\dagger \\
42.5(2 \cdot 8) \dagger \\
39.7(2 \cdot 4)^{* *}+\dagger \\
51.8(3.6)^{* * *}+\dagger \\
12.4(2 \cdot 0) \\
12.5(4.4) \\
5.1(0.8) \\
3.6(1 \cdot 1) \\
7.4(1.2) \\
25.6(5.2) \\
7.4(4.2)\end{array}$ & $\begin{aligned} 78 \cdot 4 & (5 \cdot 2)^{* * *} \\
55 \cdot 1 & (4 \cdot 2) \mathrm{tt} \\
27 \cdot 8 & (4 \cdot 4) \dagger+ \\
33 \cdot 6 & (5 \cdot 2)^{* * *} \\
12 \cdot 8 & (5 \cdot 2) \\
18 \cdot 6 & (6 \cdot 4) \\
4 \cdot 6 & (0 \cdot 4) \\
7 \cdot 8 & (2 \cdot 8) \\
4 \cdot 6 & (0 \cdot 6) \\
23 \cdot 4 & (12 \cdot 4) \\
29 \cdot 6 & (16 \cdot 6)\end{aligned}$ & $\begin{array}{l}87 \cdot 5(2 \cdot 1)^{* * *} \\
59 \cdot 0(4 \cdot 8) \dagger+ \\
24 \cdot 5(3 \cdot 6) \dagger+ \\
34 \cdot 4(2 \cdot 6)^{* *} \\
4 \cdot 6(1 \cdot 2) \\
10 \cdot 0(6 \cdot 2) \\
0 \cdot 6(0 \cdot 4) \\
4 \cdot 2(0 \cdot 8) \\
2 \cdot 2(0 \cdot 2) \\
11 \cdot 2(3 \cdot 6) \\
5 \cdot 2(1 \cdot 0)\end{array}$ & $\begin{array}{l}89 \cdot 1(2 \cdot 2)^{* *} \\
66 \cdot 2(3 \cdot 4) \dagger+ \\
20 \cdot 4(0.6) \dagger+ \\
28 \cdot 2(1 \cdot 4)^{* *} \\
5 \cdot 8(1 \cdot 0) \\
8 \cdot 2(4 \cdot 4) \\
1.6(0.2) \\
3 \cdot 8(0.4) \\
3.0(1 \cdot 4) \\
\text { ND } \\
\text { ND }\end{array}$ \\
\hline
\end{tabular}

${ }^{*} \mathrm{p}<0.05$ compared with control peripheral blood lymphocytes.

${ }^{* *} p<0 \cdot 005$ compared with control peripheral blood lymphocytes.

tp $<0.05$ compared with paired RA peripheral blood lymphocytes.

t

tp<0.005 compared with paired RA peripheral blood lympho

$\neq R A=$ rheumatoid arthritis; $S F=$ synovial fluid; $P A=$ psoriatic arthritis; $R S=$ Reiter's syndrome; $C A=$ crystal arthritis 
syndrome, and crystal arthritis was seen $(p<0.005)$, though less than that seen on RA synovial fluid lymphocytes (table 3 ). Both CD4 and CD8 cells expressed MHC class II antigens in these synovial fluid samples (table 4), though CD4+DR - $T$ lymphocytes predominated $(p<0.005)$. Most of these MHC class II antigen positive $T$ cells did not express IL2r (table 4).

Small increases in cells expressing Leu7, Leull, and B cell (SMIG) antigens were seen in RA peripheral blood, which did not reach statistical significance.

Mean fluorescence intensities for CD3, CD4, IL2r, 4F2, and MHC class II antigens on RA peripheral blood lymphocytes were lower than those seen on control peripheral blood lymphocytes, while mean fluorescence intensities for CD3, CD4, and FMC56 were lower on both RA and non-RA synovial fluid lymphocytes (except for CD4 on psoriatic arthritis lymphocytes) (table 5). None of these changes reached statistical significance, but the reduction in $\mathrm{CD} 3$ and CD4 mean fluorescence intensity was greater than that seen on lymphocytes stimulated by CD3 antibody (day 3 lymphoblasts, table 5), where downregulation of these antigens is known to occur. ${ }^{19}$ In contrast, there was no increase in mean fluorescence intensity of IL2r, 4F2, or transferrin receptor on synovial fluid lymphocytes compared with the upregulation of these antigens on the in vitro stimulated lymphocytes (table 5).

VOLUME ANALYSIS OF LYMPHOCYTES IN PERIPHERAL BLOOD AND SYNOVIAL FLUID

$T$ lymphocytes selected by gating for strong fluorescence with OKT3 (also independently with Leul) showed a bimodal scatter of volumes in peripheral blood and especially synovial fluid from patients with RA (fig la). Similar results were obtained when synovial fluid from patients with psoriatic arthritis and Reiter's syndrome was studied, showing that this was not unique to RA synovial fluid (results not shown). The larger $T$ cell population in synovial fluid contained both CD4 and CD8 cells (fig lb).

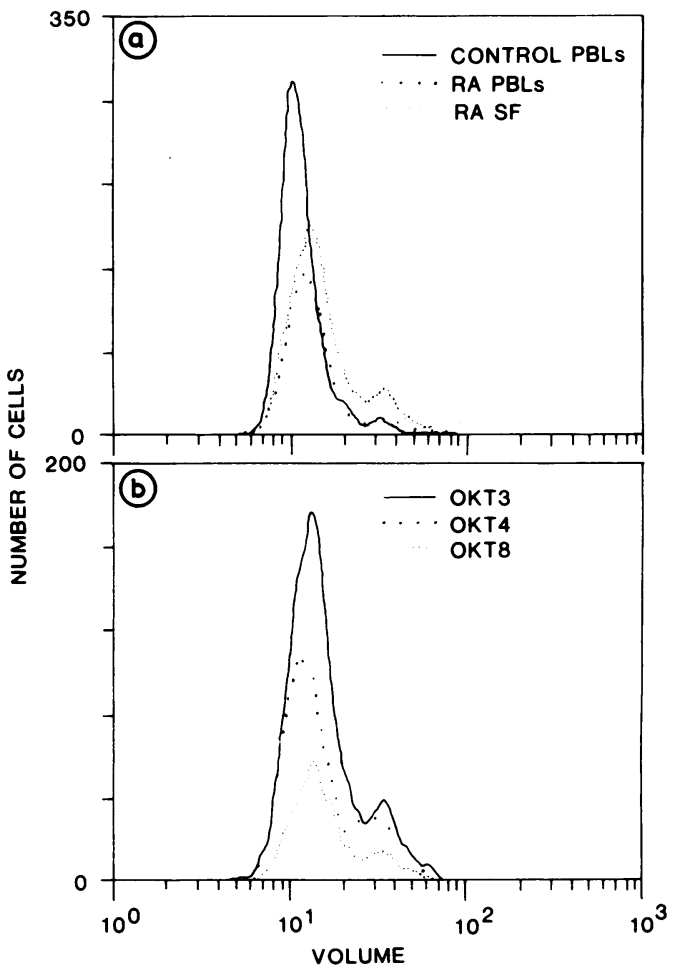

Figure 1: Volume analysis of peripheral blood lymphocytes (PBLs) and synovial fluid lymphocytes from patients with rheumatoid arthritis $(R A)$. (a) CD3 positive cells in $R A$ peripheral blood and synovial fluid; (b) CD3,CD4, and CD8 cells in RA synovial fluid.

Table 4: Dual immunofluorescence labelling of peripheral blood and synovial fluid lymphocytes from patients with rheumatoid arthritis, psoriatic arthritis, and Reiter's syndrome. Results are expressed as mean percentage positive cells (SEM)

\begin{tabular}{lcccc}
\hline & $R A \ddagger$ blood & $R A S F \mp$ & $P A \mp S F$ & $R S \ddagger S F$ \\
\hline CD4+DR+ & $8 \cdot 2(0 \cdot 8)$ & $22 \cdot 6(2 \cdot 4)^{*}$ & $16 \cdot 4(2 \cdot 2)$ & $14 \cdot 8(1 \cdot 4)$ \\
CD4+DR- & $47 \cdot 6(3 \cdot 4)$ & $21 \cdot 4(3 \cdot 2)$ & $37 \cdot 8(4 \cdot 6) \dagger$ & $36 \cdot 4(3 \cdot 2) \dagger$ \\
CD8+DR+ & $10 \cdot 4(1 \cdot 4)$ & $36 \cdot 2(6 \cdot 4)^{*}$ & $16 \cdot 8(3 \cdot 4)$ & $14 \cdot 4(2 \cdot 2)$ \\
CD8+DR- & $11 \cdot 2(1 \cdot 0)$ & $8 \cdot 6(1 \cdot 0)$ & $14 \cdot 6(2 \cdot 6)$ & $12 \cdot 4(1 \cdot 6)$ \\
DR+IL2r+ & $4 \cdot 6(0 \cdot 8)$ & $8 \cdot 4(0 \cdot 6)$ & $4 \cdot 2(1 \cdot 2)$ & $4 \cdot 8(0 \cdot 4)$ \\
DR+IL2r- & $13 \cdot 4(1 \cdot 4)$ & $46 \cdot 8(6 \cdot 2)$ & $34 \cdot 4(6 \cdot 8)$ & $1 \cdot 2 \cdot 2(0 \cdot 4)$ \\
4F2+IL2r+ & $0 \cdot 4(0 \cdot 2)$ & $1 \cdot 6(0 \cdot 4)$ & $14 \cdot 6(6 \cdot 2)$ & $0 \cdot 6(0 \cdot 2)$ \\
4F2+IL2r- & $6 \cdot 4(1 \cdot 2)$ & $13 \cdot 3(5 \cdot 4)$ & $0 \cdot 6(0 \cdot 2)$ & $4 \cdot 1(2 \cdot 4)$ \\
Tr+IL2r+ & $0 \cdot 8(0 \cdot 2)$ & $2 \cdot 3(1 \cdot 2)$ & $4 \cdot 2(1 \cdot 2)$ & $0 \cdot 8(0 \cdot 4)$ \\
Tr+IL2r- & $4 \cdot 9(1 \cdot 6)$ & $11 \cdot 6(4 \cdot 6)$ & & $4 \cdot 4(1 \cdot 4)$
\end{tabular}

${ }^{*} \mathrm{p}<0.005$ compared with paired RA peripheral blood lymphocytes.

$t \mathrm{p}<0.05$ compared with RA synovial fluid lymphocytes.

$t \mathrm{p}<0.05$ compared with $\mathrm{RA}$ synovial fluid lymphocytes.
$\ddagger \mathrm{RA}=$ rheumatoid arthritis; $\mathrm{SF}=$ synovial fluid; $\mathrm{PA}=$ psoriatic arthritis; $\mathrm{RS}=$ Reiter's syndrome.

Table 5: Mean fluorescence intensity for $T$ lymphocyte surface antigens in rheumatoid arthritis, psoriatic arthritis, and Reiter's syndrome peripheral blood and synovial fluid as well as CD3 antibody stimulated control peripheral blood lymphocytes. Values are means $(S D)$

\begin{tabular}{|c|c|c|c|c|c|c|c|c|}
\hline Patient group & $C D 3$ & $C D 4$ & $C D 8$ & $I L 2 r$ & FMC56 & $4 F 2$ & $T r^{*}$ & $\begin{array}{l}\text { MHC } \\
\text { class II }\end{array}$ \\
\hline $\begin{array}{l}\text { RA* blood }^{*} \\
\text { RA SF* } \\
\text { PA* blood } \\
\text { PA SF } \\
\text { RS* blood } \\
\text { RS SF } \\
\text { Control blood } \\
\text { Day 3 }\end{array}$ & $\begin{array}{ll}124 \cdot 34 & (82 \cdot 7) \\
114 \cdot 1 & (68 \cdot 4) \\
207 \cdot 1 & (58 \cdot 6) \\
159 & (32) \\
254 & (85 \cdot 8) \\
129 \cdot 6 & (47 \cdot 4) \\
193 \cdot 7 & (66)\end{array}$ & $\begin{aligned} 72.58 & (41 \cdot 6) \\
94.8 & (50.5) \\
102.6 & (64) \\
123 & (77 \cdot 6) \\
95.6 & (50.5) \\
95.7 & (50.1) \\
106.6 & (50.7)\end{aligned}$ & $\begin{array}{l}204 \cdot 6(103 \cdot 7) \\
242 \cdot 5(148) \\
187 \cdot 4(101) \\
228 \quad(163 \cdot 5) \\
189 \cdot 7(100) \\
196 \cdot 2(96 \cdot 7) \\
223 \cdot 1(106)\end{array}$ & $\begin{array}{l}47 \cdot 3(23 \cdot 6) \\
64 \cdot 8(31 \cdot 4) \\
42 \cdot 4(24) \\
78 \cdot 1(50 \cdot 5) \\
80 \cdot 9(30 \cdot 2) \\
66 \cdot 2(25 \cdot 6) \\
69 \cdot 1(60 \cdot 7)\end{array}$ & $\begin{array}{c}174 \cdot 3(134) \\
95 \cdot 7(57) \\
144 \cdot 1(54) \\
82 \cdot 4(43 \cdot 8) \\
203 \cdot 3(107) \\
68 \cdot 2(23) \\
130 \cdot 2(74)\end{array}$ & $\begin{array}{ll}69 \cdot 6 & (34 \cdot 3) \\
92 \cdot 7(57) \\
56 \cdot 8(37) \\
99 \cdot 8(40 \cdot 7) \\
99 \cdot 1 \quad(44 \cdot 7) \\
76 \quad(35 \cdot 3) \\
82 \quad(50 \cdot 7)\end{array}$ & $\begin{array}{l}74 \cdot 5(41) \\
87 \cdot 1(74) \\
76 \quad(76) \\
75 \cdot 4(64) \\
91 \quad(56) \\
65 \cdot 8(35) \\
76 \cdot 3(54)\end{array}$ & $\begin{array}{l}135(94) \\
197(84 \cdot 6) \\
208(103) \\
133(44 \cdot 7) \\
168(97) \\
179(139) \\
202(110)\end{array}$ \\
\hline $\begin{array}{l}\text { Day } 3 \\
\text { lymphoblas }\end{array}$ & s $178.5 \quad(54.4)$ & $127 \cdot 8 \quad(48 \cdot 6)$ & $652 \cdot 4(126 \cdot 4)$ & $345 \cdot 1(176)$ & $120 \cdot 4(66)$ & $307 \cdot 8(163)$ & $186 \cdot 3(60)$ & $228(110)$ \\
\hline
\end{tabular}

${ }^{*} \mathrm{RA}=$ rheumatoid arthritis; $\mathrm{SF}=$ synovial fluid; $\mathrm{PA}=$ psoriatic arthritis; $\mathrm{RS}=$ Reiter's syndrome; $\mathrm{Tr}=\operatorname{transferrin}$ receptor. 
This larger cell population also expressed most of the MHC class II antigens (fig 2a), as well as other lymphocyte activation markers (fig $2 b$ ), with the exception of IL2r, which was minimally expressed on both the small and large $T$ cell populations in synovial fluid. A similar volume distribution of $\mathrm{T}$ lymphocytes expressing MHC class II and lymphocyte activation markers (4F2) was seen when peripheral blood lymphocytes were stimulated in vitro with $\mathrm{CD} 3$ antibodies, with the exception that the IL2r was also expressed on the larger $T$ cell population (fig 3).

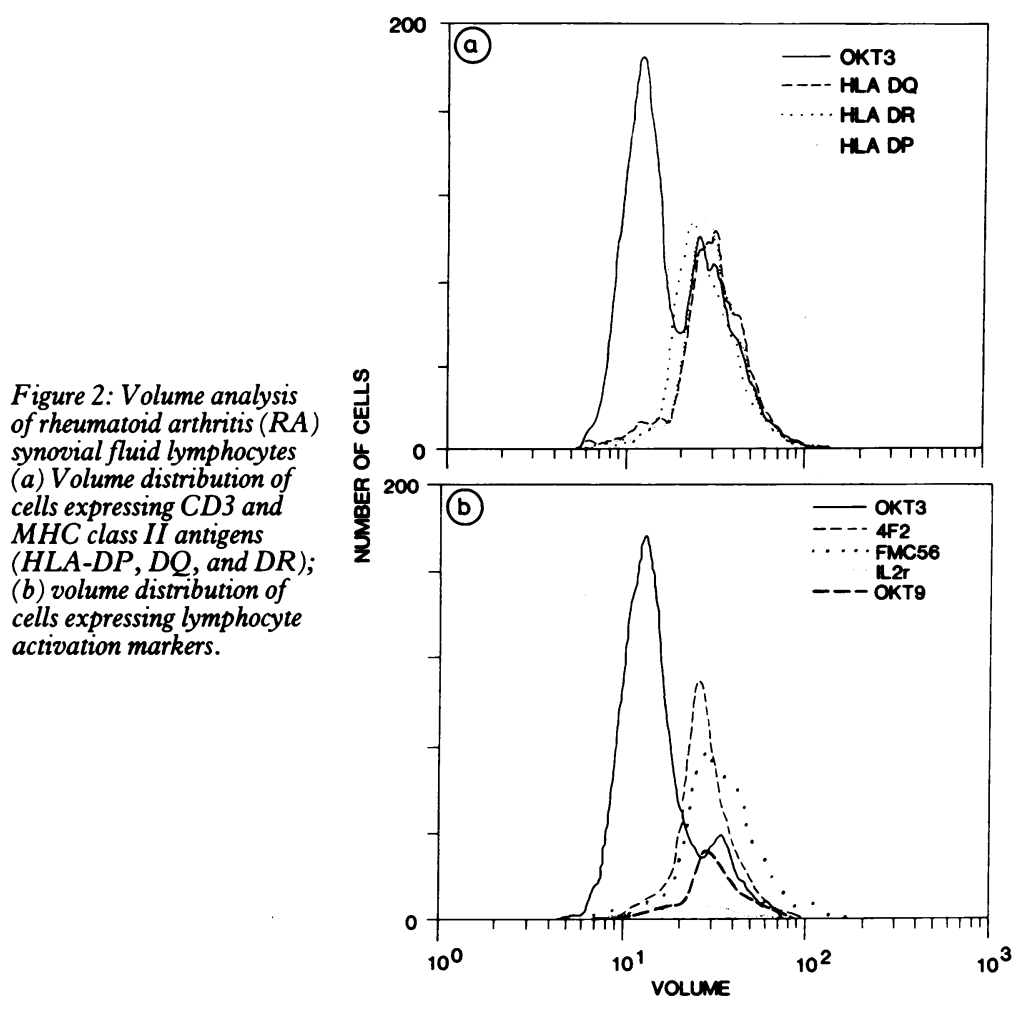

Figure 3: Volume analysis of control peripheral blood lymphocytes stimulated in vitro with $C D 3$ antibodies (OKT3). (a) Volume distribution of $T$ cells (Leul) and MHC class II antigens in stimulated and unstimulated cells; (b) volume distribution of IL 2 and $4 F 2$ antigens in stimulated and unstimulated cells.
CORRELATION BETWEEN LYMPHOCYTE SURFACE MARKERS AND CLINICAL AND LABORATORY INDICES

There was no correlation between any of the clinical indices of disease activity and the lymphocyte markers detected on peripheral blood or synovial fluid T lymphocytes of any of the patient groups studied. There was a direct correlation between MHC class II antigen expression on RA peripheral blood and synovial fluid lymphocytes and IgG $(p<0.05,0.005)$, $\operatorname{IgM}(\mathrm{p}<0.05,0.005)$, and rheumatoid factor $(\mathrm{p}<0.05,0.05)$ levels in serum and synovial fluid respectively. There was also a significant direct correlation between rheumatoid factor levels and CD8 positive cells $(p<0.05)$ and an inverse correlation with $\mathrm{CD} 4$ positive cells $(p<0.05)$ in RA synovial fluid. There were no significant correlations between cell surface marker expression and any of the clinical or laboratory indices of disease activity in the group of patients with seronegative arthritis.

\section{Discussion}

Recent publications have shown the prominence of T lymphocyte populations in synovial fluid and peripheral blood of patients with RA, and it has been proposed that this cell is important in the chronic inflammatory process seen in RA synovial tissue. ${ }^{12} 14 \quad 152326$ In vitro models of T cell activation have defined the normal pathways of $T$ cell proliferation and differentiation, involving a sequential process of IL2 production and IL2r upregulation, together with downregulation of the $T$ cell receptor, followed by reversal of these changes in the absence of continuing antigen exposure. ${ }^{19} 3940$

Although there is general agreement about the $T$ cell subsets in RA peripheral blood (excess of $\mathrm{CD} 4$ and deficiency of suppressor CD8 cells) ${ }^{10}$ and synovial fluid (excess of cytotoxic CD8 cell), ${ }^{41}$ there is disagreement about the expression of antigens indicating an activated lymphocyte state. Although most studies agree that there is a modest increase in MHC class II antigens on RA peripheral blood lymphocytes ${ }^{2-8}$ and a greater increase in expression on RA synovial fluid lymphocytes, ${ }^{5-7} 11171842$ there is considerable disagreement about expression of other $T$ lymphocyte activation markers (IL2r, transferrin receptor). ${ }^{3}{ }^{11}{ }^{15-18}$ In addition, there is considerable conflict in published work about the presence of IL2 in RA synovial fluid and the production of IL2 and expression of IL2r (high and low affinity) on RA peripheral blood and synovial fluid $\mathrm{T}$ lymphocytes. ${ }^{20-25} 4344$

In this study we have shown, like other investigators, that CD4 positive $\mathrm{T}$ cells predominate in RA peripheral blood, while CD8 positive $T$ cells predominate in RA synovial fluid. The major $T$ lymphocyte subset in RA synovial fluid expressing MHC class II antigens was the CD8 positive $T$ cell, while a minority of both CD4 and CD8 $\mathrm{T}$ cell subsets in RA peripheral blood expressed MHC class II antigens.

In vitro studies of $\mathrm{T}$ lymphocyte proliferation 
have shown an increase in size of $T$ cells stimulated with plant lectins, with coexpression of MHC class II antigens and other lymphocyte activation markers (IL2r, transferrin receptor, $4 \mathrm{~F} 2$ ), as well as downregulation of the $\mathrm{T}$ cell receptor and upregulation of the IL2r. ${ }^{19} 394045$ Whereas RA synovial fluid (and to a lesser extent peripheral blood) $\mathrm{T}$ lymphocytes show a modest decrease in mean fluorescence intensity of $\mathrm{CD} 3$ and $\mathrm{CD} 4$ antigens (compared with control peripheral blood lymphocytes), suggesting downregulation of these antigens, there is no corresponding increase in mean fluorescence intensity of the IL2r or other lymphocyte activation antigens, in contrast with the upregulation of these antigens on the $\mathrm{CD} 3$ stimulated lymphocytes.

It has been suggested that this increased expression of MHC class II antigens without a corresponding increase in other activation antigens could be due to a Gl/S stage block in lymphocyte activation in RA, ${ }^{17} 18$ possibly due to deficient IL2 production or high affinity IL2r expression, or both. ${ }^{21} 22$ An alternative explanation for these results, which we consider more likely, is that of prior activation of RA T lymphocytes, especially in intra-articular sites, by an unknown antigen. Several studies have indirectly supported this hypothesis, with the demonstration of 'very late activation' markers on RA synovial fluid ${ }^{27}$ and synovial tissue ${ }^{26}$ lymphocytes, and impaired expression of IL $2 r$ as well as deficient mitogenic responses to plant lectins, which spontaneously recover when RA peripheral blood lymphocytes are 'rested' in vitro. ${ }^{43}$ The results presented here from a large group of patients with RA support this theory of prior activation of $T$ lymphocytes in RA with persistent MHC class II antigen expression and downregulation of the $\mathrm{CD} 3$ antigen on synovial fluid lymphocytes in the absence of increased expression or upregulation of other early and mid-activation markers (transferrin receptor, 4F2, IL2r). Results presented elsewhere show impairment of mitogenic responses, IL2 production, and IL2r expression by peripheral blood and synovial fluid lymphocytes from this same group of patients, ${ }^{30}$ similar to those previously described for patients with RA..$^{20} \quad 2125$ These findings are not unique to patients with RA as similar results (increased MHC class II expression, CD3 and CD4 downregulation, and a larger subpopulation of synovial fluid lymphocytes expressing MHC class II antigens as well as other lymphocyte activation antigens with the exception of IL2r) were seen in the patients with psoriatic arthritis and Reiter's syndrome.

The results from this study suggest, therefore, that similar lymphocyte marker expression on intra-articular $\mathrm{T}$ lymphocytes is seen in RA and non-RA inflammatory arthritides. Thus if prior activation of T lymphocytes is the cause of these changes then a similar pathogenic event may be occurring in all inflammatory arthritides, with the initiating antigen(s) and the quantitative response being the only difference between these conditions.

M D Smith was supported by an NH and MRC postgraduate medical research scholarship. This research was supported in part by grants from the Arthritis Foundation of Australia (national and South Australian branches).

1 Veys E M, Hermans P, Goldstein G, Kung P, Schindler J, Van Wauwe J. Determination of $T$ lymphocyte subpopulations by monoclonal antibodies in rheumatoid arthritis. Influence of immunomodulating agents. Int $\mathcal{F}$ Immunopharmacol 1981; 3: 313-9.

2 pharmacol 1981; 3: 313-9. Winchester R J. Ia + T cells in synovial fluid and tissues of Winchester R J. Ia + T cells in synovial fluid and tissues of patients

3 Fox R I, Fong S, Sabharwal N, Carstens S A, Kung P C, Vaughan J H. Synovial fluid lymphocytes differ from peripheral blood lymphocytes in patients with rheumatoid arthritis. F Immunol 1982; 128: 351-4.

4 Veys $E M$, Hermans $P$, Schindler J, et al. Evaluation of $T$ cell subsets with monoclonal antibodies in patients with rheumatoid arthritis. I Rheumatol 1982; 9: 25-9.

5 Duke O, Panayi G S, Janossy G, Poulter L W, Tidman N. Analysis of $\mathrm{T}$ cell subsets in the peripheral blood and synovial fluid of patients with rheumatoid arthritis by means synovial fluid of patients with rheumatoid arthritis by means
of monoclonal antibodies. Ann Rheum Dis 1983; 42:357-61.

6 Kluin-Nelemans H C, van der Linden J A, Gmelig Meyling F H J, Schuurman H J. HLA-DR positive T lymphocytes in blood and synovial fluid in rheumatoid arthritis. f Rheumatol 1984; 11: 272-6.

7 Bertouch J V, Roberts-Thomson P J, Brooks P M, Bradley J. Lymphocyte subsets and inflammatory indices in synovial fluid and blood of patients with rheumatoid arthritis. $\mathcal{F}$ Rheumatol 1984; 11: 754-9.

8 Luyten F, Suykens S, Veys E M, et al. Peripheral blood T lymphocyte subpopulations determined by monoclonal antibodies in active rheumatoid arthritis. $\mathcal{F}$ Rheumatol 1986; 13: $864-9$.

9 Karlsson-Parra A, Svenson K, Hallgren R, Klareskog L, Forsum U. Peripheral blood T lymphocyte subsets in active rorsum U. Peripheral blood T lymphocyte subsets in active rheumatoid arthritis-effects of different therapies on

previously untreated patients. F Rheumatol 1986; 13: 263-8.
10 Goto M, Miyamoto T, Nishioka K, Okumura K. Selective loss of supressor $\mathrm{T}$ cells in rheumatoid arthritis patients: analysis of peripheral blood lymphocytes by 2-dimensional flow cytometry. $\mathcal{f}$ R heumatol 1986; 13: 853-7.

11 Jahn B, Burmester G R, Gramatzki M, Weseloh G, Stock P Kalden J R. Intra-articular T lymphocytes in monoarticular and oligoarticular inflammatory joint diseases. $\mathcal{F}$ Rheumatol 1986; 13: $254-8$

12 Duke O, Panayi G S, Janossy G, Poulter L W. An immunohistological analysis of lymphocyte subpopulations and their microenvironment in the synovial membranes of and their microenvironment in the synovial membranes of patients with rheumatoid arthritis using monoci

13 Meijer C J L M, deGraff-Reitsma C B, Lafeber G J M, Cats A. In situ localisation of lymphocyte subsets in synovia membranes of patients with rheumatoid arthritis with monoclonal antibodies. F Rheumatol 1982; 9: 359-65.

14 Young C L, Adamson T C, Vaughan J H, Fox R I Immunohistologic characterisation of synovial membrane lymphocytes in rheumatoid arthritis. Arthritis Rheum 1984 27: 32-9.

15 Burmester G R, Jahn B, Gramatzki M, Zacher J, Kalsen J R. Activated $T$ cells in vivo and in vitro: divergence in expression of $\mathrm{Tac}$ and $\mathrm{Ia}$ antigens in the nonblastoid small $\mathrm{T}$ cells of inflammation and normal $\mathrm{T}$ cells activated in vitro. $\mathcal{J}$ Immunol 1984; 133: 1230-4.

16 Salmon M, Bacon P A, Symmons D P M, Blann A D. Transferrin receptor bearing cells in the peripheral blood of patients with rheumatoid arthritis. Clin Exp Immunol 1985; 62: 346-52.

17 Goto M, Miyamoto T, Nishioka K. 2 dimensional flow cytometric analysis of activation antigens expressed on the synovial fluid $\mathrm{T}$ cells in rheumatoid arthritis. 7 Rheumato 1987; 14: $230-3$

18 Pitzalis C, Kingsley G, Lanchbury I S S, Murphy J, Panayi G S. Expression of HLA-DR,DQ and DP antigens and interleukin-2 receptor on synovial fluid $T$ lymphocyte interleukin-2 receptor on syn: vial ind T lymphocyte activation. I Rheumatol 1987; 14: 662-6.

19 Acuto O, Reinherz E L. The human T cell receptor. $N$ Englf Med 1985; 312: 1100-11.

20 Combe B, Pope R M, Fischbach M, Darnell B, Baron S, Talal N. Interleukin 2 in rheumatoid arthritis: production of and response to interleukin 2 in rheumatoid synovial fluid synovial tissue and peripheral blood. Clin Exp Immuno 1985; 59: 520-8.

21 Combe B, Andary M, Klein B, Clot J, Sany J. Regulation of interleukin 2 production in rheumatoid arthritis. $\mathcal{F}$ Rheumatol 1987; 14: 226-9.

22 Emery P, Wood N, Gentry K, Stockman A, Mackay I R Bernard $O$. High-affinity interleukin-2 receptors on blood lymphocytes are decreased during active rheumatoid arthritis. Arthritis Rheum 1988; 31: 1176-81.

23 Jahn B, Burmester G R, Stock P, Rohwer P, Kalden J R. Functional and phenotypical characterisation of activated $T$ cells from intra-articular sites in inflammatory join diseases. Possible modulation of the CD3 antigen. $S$ cand $\mathcal{F}$ Immunol 1987; 26: 745-54.

24 Kitas G D, Salmon M, Farr M, Gaston J S H, Bacon P A Deficient interleukin 2 production in rheumatoid arthritis: association with active disease and systemic complications. Clin Exp Immunol 1988; 73: 242-9.

25 Miyasaka N, Nakamura T, Russel I J, Talal N. Interleukin 2 
deficiencies in rheumatoid arthritis and systemic lupus erythematosus. Clin Immunol Immunopathol 1984; 31: erythem 104.

26 Cush J J, Lipsky P E. Phenotypic analysis of synovial tissue and peripheral blood lymphocytes isolated from patients with rheumatoid arthritis. Arthritis Rheum 1988; 31: 1230-8.

27 Hemler M E, Glass D, Coblyn J S, Jacobson J G. Very late activation antigens on rheumatoid synovial fluid $\mathrm{T}$ lymphocytes: association with stages of $\mathrm{T}$ cell activation. $\mathcal{f}$ Clin Invest 1986; 78: 696-702.

28 Inman R D, Klein M H. Immunological studies of serum and synovial fluid in Reiter's syndrome. Arthritis Rheum 1984; 27: $\mathrm{S} 85$.

29 Nordström D, Konttinen Y T, Bergroth V, Leirisalo-Repo M. Synovial fluid cells in Reiter's syndrome. Ann Rheum Dis 1985; 44: 852-6.

30 Smith M D, Roberts-Thomson P J. Interleukin 2 and ? interleukin 2 inhibitors in human serum and synovial fluid. 2. Mitogenic stimulation, interleukin 2 production and interleukin 2 receptor expression in rheumatoid arthritis, psoriatic arthritis and Reiter's syndrome. $\mathcal{J}$ Rheumatol 1989; 16: 897-903.

31 Ropes M W, Bennett G A, Cobb S, Jacox R, Jessar R A. 1958 revision of the diagnostic criteria for rheumatoid arthritis. revision of the diagnostic criteriaf
Arthritis Rheum 1959; 2: 16-20.

32 Wilkens R F, Arnett F C, Bitter T. Reiter's syndrome. Evaluation of preliminary criteria for definite disease. Arthritis Rheum 1981; 24: 844-9.

33 Sowden J A, Roberts-Thomson P J, Zola H. Evaluation of CD5-positive B cells in blood and synovial fluid of patients with rheumatic diseases. Rheumatol Int 1987; 7: 255-9.

34 Brooks D A, Zola H, McNamara P J, et al. Membrane antigens of human cells of the monocyte/macrophage lineage studied with monoclonal antibodies. Pathology 1983; 15: 45-52.

35 Watson A J, DeMars $R$, Trowbridge I S, Bach F H.
Detection of a novel human class II HLA antigen. Nature 1983; 304: 358-61.

36 Beckman I G R, Bradley J, Brooks D, Zola H. Delineation of serologically distinct monomorphic determinants of human MHC class II antigens: evidence of heterogeneity in their topographic distribution. Mol Immunol 1983; 21: 205-14.

37 Zola H, Furness V, Barclay S, et al. The p24 leucocyte membrane antigen: modulation associated with lymphocyte activation and differentiation. Immunology and Cell Biology 1989; 67: 63-70.

38 Haynes B F, Hemler M E, Mann D L, et al. Characterisation of a monoclonal antibody (4F2) that binds to human monocytes and to a subset of activated lymphocytes. $\mathcal{F}$ Immunol 1981; 126: 1409-14.

39 Smith K A, Cantrell D A. Interleukin 2 regulates its own receptors. Proc Natl Acad Sci USA 1985; 82: 864-8.

40 Welte $\mathrm{K}$, Andreef $M$, Platzer $\mathrm{E}$, et al. Interleukin 2 regulates the expression of TAC antigen on peripheral blood T the expression of TAC antigen on periphera
lymphocytes. $f$ Exp Med 1984; 160: 1390-403.

41 Goto M, Miyamoto T, Nishioka K, Uchida S. T cytotoxic and helper cells are markedly increased, and $\mathrm{T}$ suppressor and inducer cells are markedly decreased, in rheumatoid synovial fluids. Arthritis Rheum 1987; 30: 737-43.

42 Pincus S H, Clegg D O, Ward J R. Characterization of T cells bearing HLA-DR antigens in rheumatoid arthritis. Arthritis Rheum 1985; 28: 8-15.

43 Plater-Zyberk C, Rockett K A, Maini R N. Spontaneous recovery of the decreased expression in vitro of interleukin 2 receptors in rheumatoid arthritis. Clin Exp Immunol 1988; receptors

44 Ruschen $S$, Lemm G, Warnatz $H$. Interleukin-2 secretion by synovial fluid lymphocytes in rheumatoid arthritis. $\mathrm{Br} \mathcal{F}$ Rheumatol 1988; 27: 350-6.

45 Alcover A, Ramarli D, Richardson N E, Chang H C, Reinherz E L. Functional and molecular aspects of human $\mathrm{T}$ lymphocytes activation via $\mathrm{T} 3-\mathrm{Ti}$ and $\mathrm{T} 11$ pathways. Immunol Rev 1987; 95: 6-35. 